\title{
SOCIAL DEVELOPMENT OF CHILDREN WITH DISABILITIES IN THE INTEGRATED DEPARTMENTS IN MONTENEGRO
}

\author{
MITROVIC Ivan ${ }^{1}$, SAKOTIC Nada ${ }^{2}$, MILIC Slavko³ , NIKOLIC-ILIC Zaklina ${ }^{4}$ \\ ${ }^{I}$ Center for Social Work,Niksic (MONTENEGRO) \\ ${ }^{2}$ University of Montenegro, Faculty of Philosophy Niksic (MONTENEGRO) \\ ${ }^{3}$ Police Directorate of Montenegro (MONTENEGRO) \\ ${ }^{4}$ University Union, Belgrade Banking Academy (SERBIA) \\ E-mail:ivan.mitro0@gmail.com, ramijo@t-com.me, slavko@milic.me
}

\begin{abstract}
Socialization is not just training an individual for social life and his future role in society, but it is very important for personality formation, which is formed through learning with certain characteristics, and thus becomes a member of one culture [1]. Conflicts in the family, inconsistent discipline, affective cold, parents' hostility, poor monitoring and non-inclusion of parents in the everyday life of a minor, but also his psychological and emotional state, as well as crime and alcoholism in the family can be important factors, causers and triggers of the appearance of delinquent behaviour. The research was conducted for the duration of one school year, and it is represented by the central, southern and northern regions of Montenegro, in integrated departments at regular schools (PI Primary school 'Ilija Kisic' Herceg Novi, PI Primary school 'Vuk Karadzic' Berane, PI Primary school 'Dusan Korac' Bijelo Polje, PI Primary school 'Njegos' Kotor, PI Primary school 'Bosko Buha' Pljevlja, PI Primary school 'Olga Golovic' Niksic and PI Primary school 'Yugoslavia' Bar. Starting from the nature, essence and importance of the defined problem, the subject of our study is focused on the social development of children with disabilities, as well as on the influence of social development on the presence of problematic behaviour. The most significant results of this research, and we think that they have an impact on the social development of the child are: the fact that $23 \%$ of children grew up, lived and formed a socio-emotional status with their parent, who was not in the marital union of another child's parent. Parent's education: the most frequent is secondary school with $45.5 \%$, and the number of parents with non-completed primary school is relatively high with $14.5 \%$. A significant number of parents of children with disabilities are unemployed (fathers 26.4\%, mothers 60.0\%). We can conclude that economic characteristic can be very unfavourable for the functioning of the family. Our research shows that there are quarrels between $51.8 \%$ of parents. Regarding the presence of psychological violence against children with disabilities, we have concluded that in $14.5 \%$ of children there are indications of experiencing some form of psychological violence. The quarrel between parents, as a serious disorder in the social and overall development of children with disabilities, are expressed as a problem in the amount of $23.6 \%$ and there are indications that they reach up to $33.7 \%$. So we can say that the presence of this problem is high. It is not negligible that $40 \%$ of children with disabilities have an inadequate relation towards teachers.
\end{abstract}

Keywords: Social development, children with disabilities, unadjusted behaviour

JEL: L51

DOI: 10.5937/intrev2103093M

UDC: 159.923.5.072.59-056.31-053.5/.6(497.16)

316.614-056.31-053.5/.6

316.624.2-056.31-053.5/.6

COBISS.SR-ID 55102729 


\section{INTRODUCTION}

The family directly influences the development of a child, i.e. a minor, his upbringing, a way of understanding life circumstances and human relationships, and influences on his actions in the future. Besides the individual characteristics of a child, factors that can lead to unadjusted behaviour are low intelligence, poor school achievement, poor empathy, aggression, hyperactivity and attention deficit and family factor [2]. Therefore, even when it comes to youth delinquency, risk factors and protective factors are reduced to four groups, i.e. family factors, school factors, community-based factors, and individual factors [3]. The long-term effect of these factors can lead to the formation of negative attitudes, unfavourable self-image, ambivalence or destructive relation towards others. Children with disabilities may be less successful in overcoming developmental crises, in the process of transition from childhood to adolescence. Socialization is the process of learning through which the individual acquires socially relevant forms of behaviour and is formed as a person with all its characteristics [4]. Social development is a process of learning how to live, and how to behave in the environment of others. These are changes that lead to new relationships with others, greater independence and responsibility. The period of transition from childhood to adolescence marks the redirection and assimilation of social values. Gradual attention moves from family to broader society, with increased need for independence and responsibility. Therefore, adolescents still rely on the family, especially in terms of love, and security restrictions. Growing up in poverty is associated with many negative outcomes, firstly with health and unadjusted behaviours, and poorer school success and educational outcomes. The consequences are more serious if a child lives in extreme poverty, deprivation can leave long-term consequences. Particularly harmful is the experience of poverty in early childhood [5]. Since poverty is a stigmatized position that parents and students talk about unwillingly, timely community support is often lacking. It is therefore important to know that late interventions can have positive results. It is recommended, in cooperation with the local community, to organize concrete financial assistance. Over time, in the study of the phenomenon of social development, the focus is moved from intrapersonal to interpersonal. The centre of interest is the interaction of a child with a family group and a peer group. The aim is to integrate the child's sequences of social interaction with his current cognitions and emotions [6].

The results of a large number of studies show that the sociometric position of pupils with visual disturbances is significantly worse than the sociometric situation occupied by pupils without visual disturbance [7][8][9][10]state that students with visual disturbance (regardless of visual acuity) have a worse sociometric status than pupils without visual disturbances. More often they occupy a low, rarely high sociometric position in the classroom, compared to peers without visual disturbances. The authors explain that students with severe visual disturbances, even in 30\% of cases, occupy a low sociometric status. If we know that visual disturbance is one of the least developed disturbances and we see the extent of non-acceptance by peers, then we can say with certainty that school factors are responsible for some unaccepted behaviour in children with disabilities. Intellectual difficulties, according to the latest definition of the American Association for Mental Retardation, are described by a significant limitation in overall intellectual functioning and in adaptive behaviour, expressed in conceptual, social and practical adaptive skills. They appear before the age of 18 depending on the interaction with the social environment [11]. Intellectual difficulties, according to the latest definition of the American Association for Mental Retardation, are described by a significant limitation in overall intellectual functioning, and in adaptive behaviour, expressed in conceptual, social and practical adaptive skills. Children with intellectual disabilities often go through a crisis during the first school years. Then they come to know that they are different, and that they may not be fully responsive to all social environments. Reactions to this cognition can be turned either inwardly (depression and feeling of worthlessness) or outside (aggression and motor disorder). Although undesirable forms of behaviour are common among people with intellectual disabilities, it is difficult to define them because they depend on the perception of people from the environment of these persons. Unaccepted behaviour is a major source of additional difficulties for children, young people and adults with intellectual disabilities. They represent additional suffering for both the individual and her parents, causing stress, which increases the likelihood of institutionalization, and reduced social integration and employment [12].conduct a research aimed at examining the frequency and characteristics of undesirable behaviour in children with intellectual disabilities, with a sample of 84 students, ages 7 to 14 years. Based on the conducted research, it was 
concluded that there is a significant difference in the frequency and characteristics of undesirable behavioural patterns in relation to gender, where boys showed a higher level of undesirable behaviour in relation to girls; in relation to age, where children with intellectual disabilities of the elderly have shown more undesirable behaviour in relation to children with intellectual disabilities of the younger age. The creator of the psychosocial theory, Erik Erikson [13] does not limit the development of childhood but considers it to be a process that extends throughout life. Cognitive social transition to the adult world leads to the nervous system matured, reaching formal operations, then overcoming child egocentrism on the cognitive and social plan, and social experience acquired in the family, school and peer group. In the research "Parents' attitudes towards children with behavioural disorders [14], the authors state that the problem of research is unaccepted behaviour in children and young people, and the role of parents in the prevention and rehabilitation of children with disorderly behaviour, in order to preventing the consequences for the education and development of children. The aim of the work was to examine and determine whether the attitudes of parents towards children with unaccepted behaviour were positive or negative. The sample of respondents consisted of 220 parents of eight-year students, nine-year elementary school. The results of the study showed that parents saw different forms of unadjusted behaviour in their children. Children begin to manifest unaccepted behaviour in different periods of their lives. Parents are difficulty communicating with children with unsuitable behaviour. Parents most often solve unaccompanied behaviour of the child with the help of experts (pedagogue, psychologist and social worker). Respondents had the view that children with unadjusted behaviour should be helped, and they also believe that children with unadjusted behaviour are not always adequately accepted by their peers. Cooperation between family and school is not always adequate when it comes to addressing the problem of children with unadjusted behaviour.

\section{OBJECTIVES OF RESEARCHES}

Objectives of researches are: 1 . Identify the level of social development of children with disabilities, 2. Identify forms of behavioural disorders in children with disabilities, 3. Identify the impact of social characteristics of families on children with disabilities with problematic behaviour. Sample: Children attending integrated classes (seven classes) at regular schools PS "Olga Golovic" Niksic, PS "Bosko Buha“" Pljevlja, PS “Njegos“ Kotor, PS “Jugoslavija“"Bar, PS „Ilija Kisic“-Zelenika, PS "Dusan Korac" Bijelo Polje and PS "Vuk Karadzic" Berane. Instruments and test procedures: The research will use the Diagnostic Protocol for the Study of Social Development and Behavioural Disorder. Data are obtained from the class elder and the social worker. Basic data (school, class, disorder - we take data from the routing solution, gender, age). Family status including the following indicators (marital origin, marital status, family structure, number of siblings). Socio-economic characteristics of families (educational background of parents, parents' interests, working status of parents, residential status of a family, material status, use of material benefits, family emigration). Family health status, Deviant behaviour (alcoholism, other deviant behaviours). Family conflicts (quarrels between parents, fights between parents). Violence against children in the family (physical violence, psychological, sexual). Problems in the pedagogic-educational process (general success, behaviour on the class, relationship of children to teachers, relationship of children towards peers, absence of children from school, cooperation of parents with school). Risky and deviant behaviour (socializing children with delinquent peers, aggressive behaviour of children, auto-aggressive behaviour of children, escaping children from school, escaping respondent from house, begging and vagrancy of children, committing violations and criminal offenses by children, misuse of psychoactive substances by children). In addition to this basic research tool, an open-unstructured interview method will be used. 


\section{RESULTS}

Table 1. Distribution of children with disabilities according to the school they attend

\begin{tabular}{|l|c|c|}
\hline \multirow{2}{*}{ School name } & \multicolumn{2}{|c|}{ Children } \\
\cline { 2 - 3 } & No. & \% \\
\hline PS „Olga Golovic” Niksic & 22 & 20.0 \\
\hline PS „BoskoBuha” Pljevlja & 15 & 13.6 \\
\hline PS „Njegos” Kotor & 8 & 7.3 \\
\hline PS ,Jugoslavija” Bar & 19 & 17.3 \\
\hline PS „IlijaKisic” Zelenika & 22 & 20.0 \\
\hline $\begin{array}{l}\text { PS ,DušanKorac” } \\
\text { BijeloPolje }\end{array}$ & 5 & 4.5 \\
\hline PS ,Vuk Karadzic” Berane & 19 & 17.3 \\
\hline Total: & $\mathbf{1 1 0}$ & $\mathbf{1 0 0}$ \\
\hline
\end{tabular}

Table 3. Distribution of children with disabilities according to primary disorder in development

\begin{tabular}{|l|c|c|}
\hline \multirow{2}{*}{$\begin{array}{l}\text { Primary developmental } \\
\text { disorder }\end{array}$} & \multicolumn{2}{|c|}{ Children } \\
\cline { 2 - 3 } Mental disability & 94 & 85.5 \\
\hline Visual impairment & 3 & 2.7 \\
\hline Hearing impairment & 1 & 0.9 \\
\hline Physical disability & 12 & 10.9 \\
\hline Total: & 110 & 100 \\
\hline
\end{tabular}

Table 4. Distribution of children with disabilities by sex

\begin{tabular}{|l|c|c|}
\hline \multirow{2}{*}{ Sex } & \multicolumn{2}{|c}{ Children } \\
\cline { 2 - 3 } & No. & \\
\hline Male & 76 & Male \\
\hline Female & 34 & Female \\
\hline Total: & 110 & Total \\
\hline
\end{tabular}

Distribution of children with disabilities by sex, shows us that the boys are twice more than girls
Table 2. Distribution of children with disabilities according to the class they attend

\begin{tabular}{|l|c|c|}
\hline \multirow{2}{*}{ Class at school } & \multicolumn{2}{|c|}{ Children } \\
\cline { 2 - 3 } & No. & \% \\
\hline I & 12 & 10.9 \\
\hline II & 15 & 13.6 \\
\hline III & 15 & 13.6 \\
\hline IV & 10 & 9.1 \\
\hline V & 16 & 14.6 \\
\hline VI & 8 & 7.3 \\
\hline VII & 9 & 8.2 \\
\hline VIII & 10 & 9.1 \\
\hline IX & 15 & 13.6 \\
\hline Total: & $\mathbf{1 1 0}$ & $\mathbf{1 0 0}$ \\
\hline
\end{tabular}

According to the primary developmental disorder, respondents are distributed as seen in four categories, of which the most dominant mental disability

Table 5. Distribution of children with disabilities by age

\begin{tabular}{|l|c|c|}
\hline \multirow{2}{*}{ Age } & \multicolumn{2}{c|}{ Children } \\
\cline { 2 - 3 } & No. & \\
\hline $7-10$ & 33 & $7-10$ \\
\hline $11-14$ & 45 & $11-14$ \\
\hline $15-18$ & 32 & $15-18$ \\
\hline $19-24$ & & $19-24$ \\
\hline Total: & 110 & Total \\
\hline
\end{tabular}

The sample includes respondents from 7-18 years. 
Table 6. Distribution of the survey population according to marital birth origin

\begin{tabular}{|l|c|c|}
\hline Marital origin & No. & $\%$ \\
\hline Marital born & 90 & 81.9 \\
\hline Illegitimate recognized paternity & 15 & 13.6 \\
\hline $\begin{array}{l}\text { Illegitimate unrecognized } \\
\text { paternity }\end{array}$ & & \\
\hline Illegitimate unknown paternity & 1 & 0.9 \\
\hline Unknown parents & 4 & 3.6 \\
\hline Total: & 110 & 100 \\
\hline
\end{tabular}

Most of our surveyed population comes from the marital community $81.9 \%$, illegitimate community $13.6 \%$, while unknown parents $3.6 \%$.
Table 8. Structure of the family of children with disabilities

\begin{tabular}{|l|c|c|}
\hline Child lives with & No. & $\%$ \\
\hline Both parents & 92 & 83.6 \\
\hline Mother & 6 & 5.5 \\
\hline Father & 3 & 2.7 \\
\hline Tutor & 9 & 8.2 \\
\hline $\begin{array}{l}\text { In the home for children } \\
\text { without parental care }\end{array}$ & 110 & 100 \\
\hline In extended family & & \\
\hline Total: & & \\
\hline
\end{tabular}

By analysing the data presented in Table 8, $83.6 \%$ of children live in a complete family, nuclear or expanded type, 8.2\% in a home for children without parental care, with a mother $5.5 \%$, and with father $2,7 \%$.
Table 7. Marital status of parents of children with disabilities

\begin{tabular}{|l|c|c|}
\hline Marital origin & No. & $\%$ \\
\hline Married & 84 & 76.4 \\
\hline Divorced & 5 & 4.5 \\
\hline In a divorced dispute & 1 & 0.9 \\
\hline $\begin{array}{l}\text { Longer absence of one of } \\
\text { the parents }\end{array}$ & 1 & 1.8 \\
\hline The death of one parent & 2 & \\
\hline They never lived together & 1 & 0.9 \\
\hline One parent unknown & 3 & 2.7 \\
\hline Both parents are unknown & & \\
\hline Dead parents & 13 & 11.8 \\
\hline Illegitimate community & 109 & 99.1 \\
\hline Total: &
\end{tabular}

Parents of the surveyed population of children with disabilities live in a marital community $76.4 \%$. We identified the fact that $23 \%$ of children grew up, lived and formed a socio-emotional status with their parent, who were not in the marital community of another parent.

Table 9. Number of siblings (brothers and sisters) of children with disabilities

\begin{tabular}{|c|c|c|}
\hline Number of siblings & No. & $\%$ \\
\hline Only child & 20 & 18.2 \\
\hline One brother/sister & 45 & 40.9 \\
\hline $\begin{array}{l}\text { Two and more } \\
\text { brothers/sisters }\end{array}$ & 45 & 40.9 \\
\hline Total: & 110 & 100 \\
\hline $\begin{array}{l}\text { The presented data show tha } \\
40.9 \% \text { examinees have one } \\
\text { Also, } 40.9 \% \text { have two or mo } \\
\text { practically means that } 80.1 \% \\
\text { have one or two siblings. }\end{array}$ & $\begin{array}{l}\text { most o } \\
\text { other o } \\
\text { siblin } \\
\text { of child }\end{array}$ & $\begin{array}{l}\text { ne } \\
\text { ister. } \\
\text { This } \\
\text { The }\end{array}$ \\
\hline
\end{tabular}


Table 10. School education/educational level of parents of children with disabilities

\begin{tabular}{|l|c|c|l|c}
\hline $\begin{array}{l}\text { Educational } \\
\text { background of } \\
\text { children's } \\
\text { parents }\end{array}$ & \multicolumn{2}{|c|}{ Father } & \multicolumn{2}{c}{ Mother } \\
\cline { 2 - 5 } & No. & $\mathbf{\%}$ & & No. \\
\hline Unfinished PS & 16 & 14.5 & Unfinished PS & 16 \\
\hline Finished PS & 10 & 9.1 & Finished PS & 10 \\
\hline $\begin{array}{l}\text { Qualified/Highly } \\
\text { qualified }\end{array}$ & 15 & 13.6 & $\begin{array}{l}\text { Qualified/Highl } \\
\text { y qualified }\end{array}$ & 15 \\
\hline Special school & 1 & 0.9 & Special school & 1 \\
\hline $\begin{array}{l}\text { Secondary } \\
\text { education }\end{array}$ & 50 & 45.5 & $\begin{array}{l}\text { Secondary } \\
\text { education }\end{array}$ & 50 \\
\hline $\begin{array}{l}\text { Higher education } \\
\text { University }\end{array}$ & 5 & 4.5 & $\begin{array}{l}\text { Higher } \\
\text { education }\end{array}$ & 5 \\
\hline education & 11 & 10 & $\begin{array}{l}\text { University } \\
\text { education }\end{array}$ & 11 \\
\hline Master/Doctor & & & Master/Doctor & \\
\hline Total: & $\mathbf{1 0 8}$ & $\mathbf{9 8 . 2}$ & Total: & $\mathbf{1 0 8}$ \\
\hline
\end{tabular}

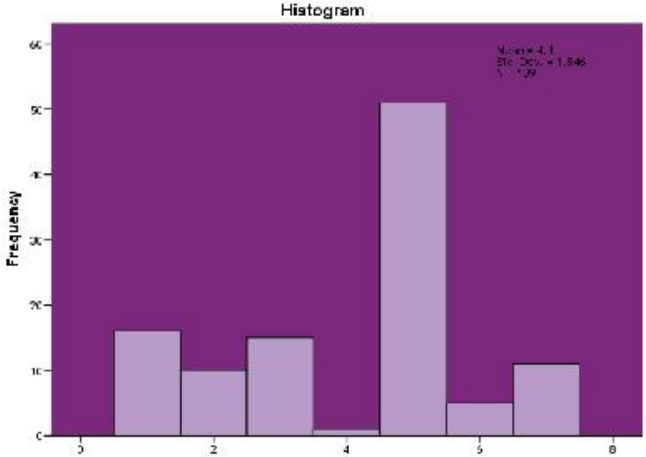

Degree of schooling of parents

According to the presented data, the fathers of the examined children have completed elementary school in $9.1 \%$. The higher education rate is $10 \%$, Qualified/Highly qualified is $13.6 \%$, Secondary education is $45.5 \%$ and it is the most frequent, the relatively high is the number of parents with unfinished primary school and it is $14.5 \%$.

Similar to the previous one is the distribution of the educational level of mothers of disabled children. Finished Secondary school with $44.5 \%$ is the most frequent.

Table 11. Interest of parents of children with disabilities

\begin{tabular}{|l|c|c|c|c|}
\hline \multirow{2}{*}{$\begin{array}{l}\text { The interest of parents of children with } \\
\text { disabilities }\end{array}$} & \multicolumn{2}{|c|}{ Father } & \multicolumn{2}{c|}{ Mother } \\
\cline { 2 - 5 } & No. & $\mathbf{\%}$ & No. & \% \\
\hline Industry / Mining & 1 & 0.9 & 2 & 1.8 \\
\hline Agriculture / Forestry & 3 & 2.7 & & \\
\hline Construction & 25 & 22.7 & & \\
\hline Commerce & 3 & 2.7 & 21 & 19.1 \\
\hline Finance / technical and business services & 3 & 2.7 & 2 & 1.8 \\
\hline Catering / Craft & 28 & 25.5 & 21 & 19.1 \\
\hline Housing/communal services & 12 & 10.9 & 9 & 8.2 \\
\hline Education, science, culture, information & 1 & 0.9 & 5 & 4.5 \\
\hline Health, social welfare & & & 1 & 0.9 \\
\hline State authorities & 17 & 15.5 & 8 & 7.3 \\
\hline Without interest & 15 & 13.6 & 41 & 37.3 \\
\hline Total: & $\mathbf{1 0 9}$ & $\mathbf{9 9 . 1}$ & $\mathbf{1 1 0}$ & $\mathbf{1 0 0}$ \\
\hline
\end{tabular}

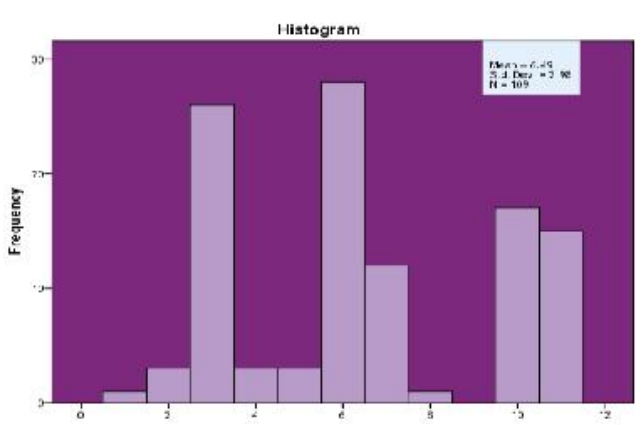

Profession of parents-father

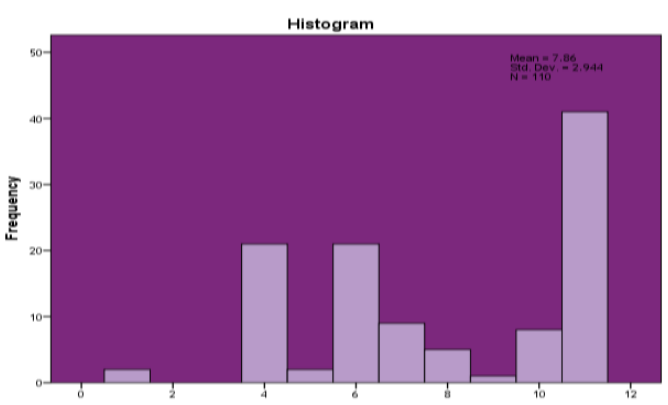

] Profession of parents-mother

The number of parents of children with disabilities without a certain occupation is relatively high, fathers $13.6 \%$, mothers $33.3 \%$. It can be right to say that this socio-economic benefit can be very 
favorably reflected in the performance of family functions, especially economic and pedagogicaleducational.

Table 12. Working status of parents of children with disabilities

\begin{tabular}{|l|c|c|c|c|}
\hline \multirow{2}{*}{$\begin{array}{c}\text { Working } \\
\text { Wtatus of } \\
\text { parents }\end{array}$} & \multicolumn{2}{|c|}{ Father } & \multicolumn{2}{c|}{ Mother } \\
\cline { 2 - 5 } & No. & $\mathbf{\%}$ & No. & $\mathbf{\%}$ \\
\hline On indefinitely & 44 & 40.0 & 32 & 29.1 \\
\hline On certain & 33 & 30.0 & 11 & 10.0 \\
\hline Pensioner & 3 & 1.8 & 1 & 0.9 \\
\hline Unemployed & 29 & 26.4 & 66 & 60.0 \\
\hline Total: & $\mathbf{1 0 9}$ & $\mathbf{9 8 . 2}$ & $\mathbf{1 1 0}$ & $\mathbf{1 0 0}$ \\
\hline
\end{tabular}

Parents of the surveyed population are employed indefinitely (40.0\% of fathers and $29.1 \%$ of mothers). A significant number of parents of children with disabilities are unemployed (fathers Employment status of parents-mother and father $26.4 \%$, mothers $60.0 \%)$. We can conclude that economic characteristics can be very unfavourable for the functioning of the family.

Table 13. Housing status of families of children with disabilities

\begin{tabular}{|c|c|c|}
\hline Housing status & No. & \% \\
\hline Subtenants & 37 & 33.6 \\
\hline $\begin{array}{c}\text { Owners of } \\
\text { apartments/house }\end{array}$ & 63 & 57.3 \\
\hline $\begin{array}{c}\text { Necessary } \\
\text { accommodation / illegal }\end{array}$ & 10 & 9.1 \\
\hline Total: & $\mathbf{1 1 0}$ & $\mathbf{1 0 0}$ \\
\hline
\end{tabular}

The housing situation in the family of children with disabilities is relatively poor, with subtenants and necessary accommodation $43.0 \%$.

Table 15. Use of material benefits

\begin{tabular}{|l|c|c|}
\hline Using of benefits & No. & \% \\
\hline Increased child allowance & 35 & 31.8 \\
\hline Child allowance & 27 & 24.5 \\
\hline Material support & 32 & 29.1 \\
\hline $\begin{array}{l}\text { Allowance for care and } \\
\text { assistance }\end{array}$ & 58 & 52.7 \\
\hline Personal disability & 63 & 57.3 \\
\hline Total: & $\mathbf{2 1 5}$ & $\mathbf{1 9 5 . 4}$ \\
\hline
\end{tabular}

Because of a better and more realistic view of the overall economic status of the families of

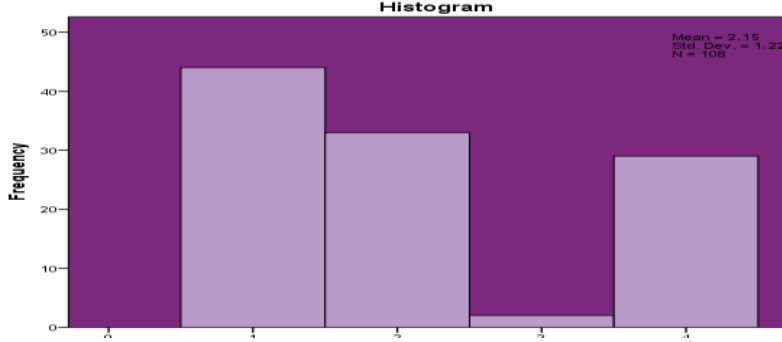

Working status of parents - father Histogram

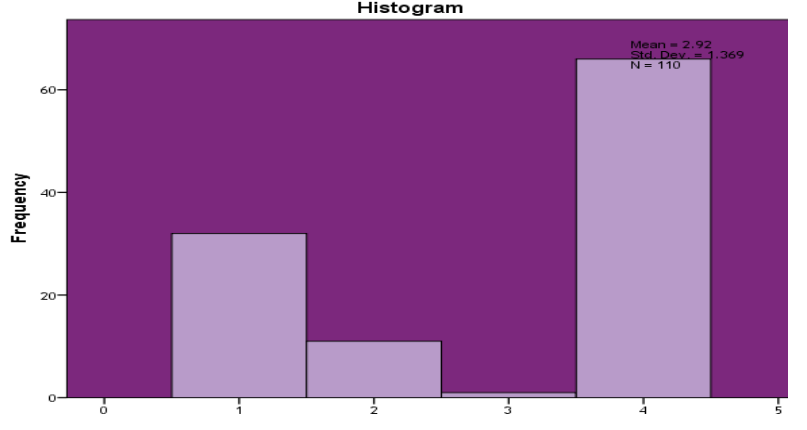

Working status of parents - mother

Table 14. Material status of families of children with disabilities

\begin{tabular}{|c|c|c|}
\hline Material status & $\begin{array}{ll} & \text { No } \\
\text {. } & \end{array}$ & $\%$ \\
\hline Favorable & 12 & $9 \begin{array}{ll} & 10 .\end{array}$ \\
\hline Average & 47 & $7 \begin{array}{ll} & 42\end{array}$ \\
\hline Unfavorable & 51 & $4 \quad 46$ \\
\hline Total: & $0^{11}$ & 0 10 \\
\hline
\end{tabular}

The situation regarding the material status of families of children with disabilities is significantly unfavourable.

Table 16. Emigration of families of children with disabilities

\begin{tabular}{|l|c|c|}
\hline Emigration & No. & \% \\
\hline Refugees & 2 & 1.8 \\
\hline Not refugees & 108 & 98.2 \\
\hline Total: & $\mathbf{1 1 0}$ & $\mathbf{1 0 0}$ \\
\hline
\end{tabular}

Children with disabilities tolerate on more difficult way change in the environment. Traumas and stresses that are resulted from these events surely leave visible consequences at all levels of their functioning. Our research shows that there are only two families of refugee status. 
the surveyed population, data on the use of various types of material benefits were collected and processed. Families use some form of prestige, and most of all, care and assistance allowance (52.7\%) and personal disability allowance (57.3\%). Families are in a bad financial situation, i.e. in a state of social need.

Table 17. Health status of family members of children with disabilities

\begin{tabular}{|l|c|c|c|c|c|c|c|c|}
\hline \multirow{2}{*}{ Health status } & \multicolumn{2}{|c|}{ Father } & \multicolumn{2}{c|}{ Mother } & \multicolumn{2}{|c|}{ Brother } & \multicolumn{2}{c|}{ Sister } \\
\cline { 2 - 10 } & No. & $\%$ & No. & $\%$ & No. & $\%$ & No. & $\%$ \\
\hline Without health problems & 88 & 80.0 & 90 & 81.8 & 66 & 98.5 & 65 & 100 \\
\hline Organic chronic disease & 16 & 14.6 & 14 & 12.7 & & & & \\
\hline Mental illness & 2 & 1.8 & 4 & 3.6 & & & & \\
\hline Disability & 3 & 2.7 & 2 & 1.8 & 1 & 1.1 & & \\
\hline & 109 & 100 & 110 & 100 & 67 & 100 & 65 & 100 \\
\hline
\end{tabular}

Brothers and sisters of children with disabilities have a small number of health problems, while parents have more health problems.

Table 19. Other deviant behaviour of family members of children with disabilities, and jail punishment research,

\begin{tabular}{|l|c|c|c|c|c|c|c|c|}
\hline \multirow{2}{*}{ Deviant behavior } & \multicolumn{2}{|c|}{ Narcotism } & \multicolumn{2}{|c|}{ Criminality } & \multicolumn{2}{|c|}{ Prostitution } & \multicolumn{2}{|c|}{$\begin{array}{c}\text { Jail } \\
\text { punishment }\end{array}$} \\
\cline { 2 - 10 } & No. & $\%$ & No. & $\%$ & No. & $\%$ & No. & $\%$ \\
\hline There is no problem & 110 & 100 & 110 & 100 & 110 & 100 & 110 & 100 \\
\hline There is a problem & & & & & & & & \\
\hline There are clues & & & & & & & & \\
\hline Total: & 110 & 100 & 110 & 100 & 110 & 100 & 110 & 100 \\
\hline
\end{tabular}

These data deserve an additional comment. In this research, we were faced with an objective methodological limitation, that is to get family data from teachers of the integrated classes, bearing in mind the parents' unwillingness to respond honestly the offered questions.

Table 20. Quarrels between parents of children with disabilities

\begin{tabular}{|l|c|c|}
\hline Quarrels & No. & \% \\
\hline There is no problem & 46 & 41.8 \\
\hline There is a problem & 57 & 51.8 \\
\hline There are clues & 7 & 6.4 \\
\hline Total: & $\mathbf{1 1 0}$ & $\mathbf{1 0 0}$ \\
\hline
\end{tabular}

Table 18. Alcoholism in the family of children with disabilities

\begin{tabular}{|l|c|c|}
\hline Alcoholism & No. & \% \\
\hline There is no problem & 65 & 59.1 \\
\hline There is a problem & 29 & 26.4 \\
\hline There are clues & 16 & 14.5 \\
\hline Total: & $\mathbf{1 1 0}$ & $\mathbf{1 0 0}$ \\
\hline
\end{tabular}

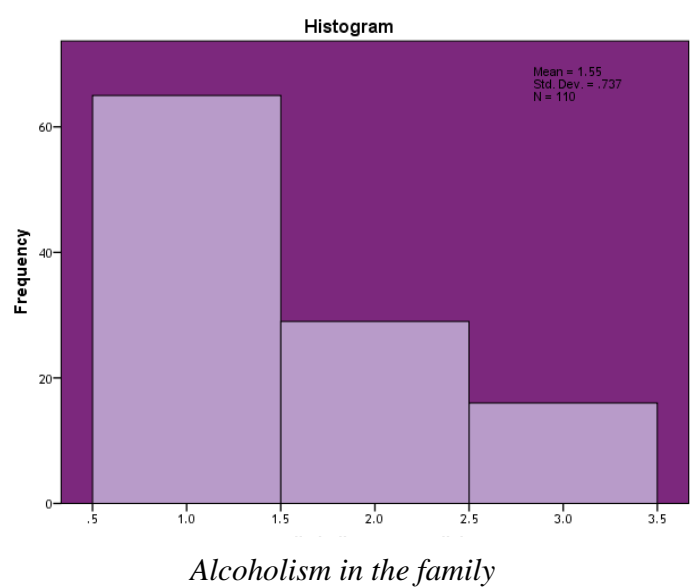

According to the data, in almost $40 \%$ there is a problem and indications of alcoholism in the families of children with disabilities

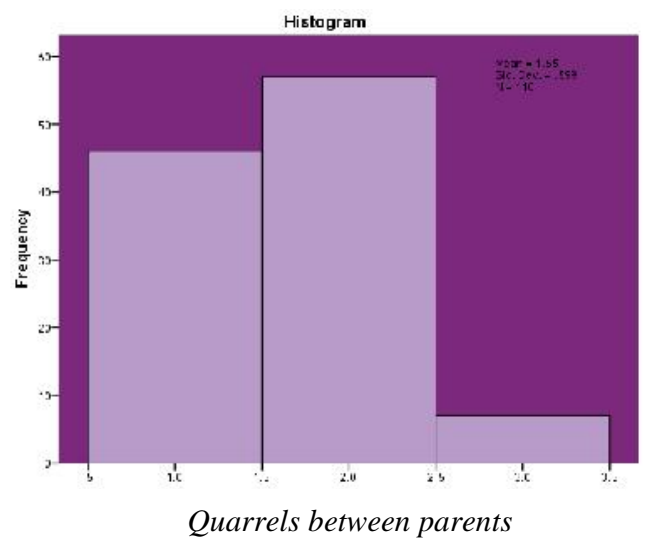


Chronic family conflicts, primarily expressed through the presence of quarrels and fights between parents, are an important factor in the social development of children with disabilities. More specifically, family conflicts constitute a significant risk factor for the emergence of various forms of psychosomatic and behavioural disorders in this particularly vulnerable group of children. The quarrels between parents are included in this research in a form of disrupted relationships, which have elements of psychological violence (and are often only a prelude to physical violence between partners/parents), and therefore we place this phenomenon in a broader whole, in which we present the presence of violence in the families of children with disabilities.

Table 21. Fights between parents of children with disabilities

\begin{tabular}{|l|c|c|}
\hline Fights & Number & $\mathbf{\%}$ \\
\hline There is no problem & 47 & 42.7 \\
\hline There is problem & 26 & 23.6 \\
\hline There are clues & 37 & 33.7 \\
\hline Total: & $\mathbf{1 1 0}$ & $\mathbf{1 0 0}$ \\
\hline
\end{tabular}

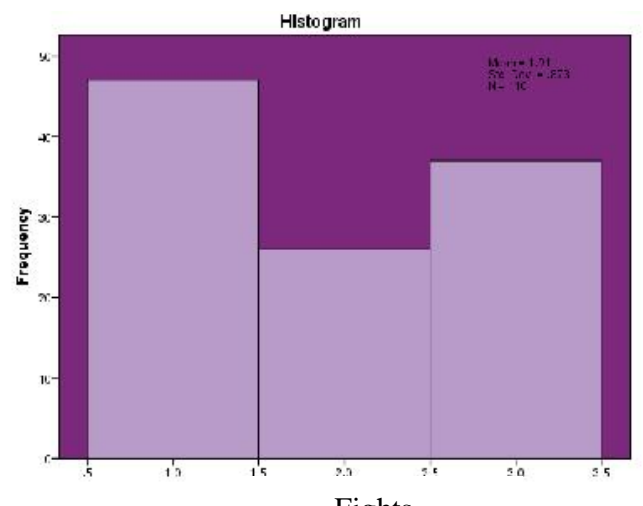

Fights between parents, as a serious disorder in the social and overall development of children with disabilities, is expressed as a problem of $23.6 \%$ and there are clues of $33.7 \%$. So, we can say that the presence of this problem is high. In terms of partner relationships, researches show that spouses from these families have incomparably weaker harmony, compared to partners who do not have a child with disabilities. Poor harmony, which is usually the cause of partner conflicts, is most often due to the distribution of housework, child upbringing, leisure time, disturbed communications [15].

Table 22. Neglecting children with disabilities

\begin{tabular}{|l|c|c|}
\hline Neglecting & No. & \% \\
\hline It does not exist & 52 & 47.2 \\
\hline Underfed & 2 & 1.8 \\
\hline Inadeq. clothing and footwear & 9 & 8.2 \\
\hline Hygienic neglected & 22 & 20.0 \\
\hline Inadeq. health care & 17 & 15.5 \\
\hline Multiple neglected & 8 & 7.3 \\
\hline Total: & $\mathbf{1 1 0}$ & $\mathbf{1 0 0}$ \\
\hline
\end{tabular}

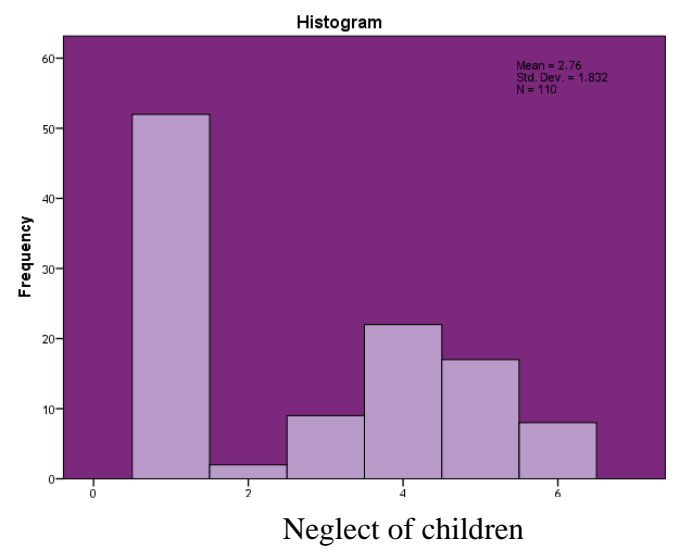

A key observation is that $47 \%$ of children with disabilities experience some form of neglect. The most present is hygienic neglect $20 \%$ and inadequate health care $15.5 \%$.

Table 23. Physical violence against children with disabilities in the family

\begin{tabular}{|l|c|c|}
\hline Physical violence & No. & \% \\
\hline There is no problem & 87 & 79.1 \\
\hline There is a problem & 5 & 4.5 \\
\hline There are clues & 18 & 16.4 \\
\hline Total: & $\mathbf{1 1 0}$ & $\mathbf{1 0 0}$ \\
\hline
\end{tabular}

Table 24. Psychical violence against children with disabilities in the family

\begin{tabular}{|l|c|c|}
\hline Psychical violence & No. & \% \\
\hline There is no problem & 94 & 85.5 \\
\hline There is a problem & & \\
\hline There are clues & 16 & 14.5 \\
\hline Total: & $\mathbf{1 1 0}$ & $\mathbf{1 0 0}$ \\
\hline
\end{tabular}


In this study, under the general concept of violence against a child with disabilities, it means 'such relationships and behaviours of individuals of social groups, whom with the use of force, inflicts pain, physical and mental damages, endanger the health and physical and psychological integrity of the personality, and prevent the normal development of a child with disabilities [16].

Table 25. Sexual violence against children with disabilities in the family

\begin{tabular}{|l|c|c|}
\hline Sexual violence & No. & \% \\
\hline There is no problem & 110 & 100 \\
\hline There is problem & & \\
\hline There are clues & & \\
\hline Total: & $\mathbf{1 1 0}$ & $\mathbf{1 0 0}$ \\
\hline
\end{tabular}

The results show that there was no sexual violence against children with disabilities.
According to the presence of psychological violence against children with disabilities, we have concluded that in $14.5 \%$ of children exist signs of experiencing some form of psychological violence. The experts, who gave us answers in just over $85 \%$ of cases, are sure that these children have not had negative experiences of psychological abuse in their families.

Table 26. General school success of children

\begin{tabular}{|l|c|c}
\hline School success & No. & \% \\
\hline Excellent & 19 & 17.3 \\
\hline Very good & 26 & 23.6 \\
\hline Good & 49 & 44.5 \\
\hline Satisfying & 9 & 8.2 \\
\hline Bad marks & 1 & 0.9 \\
\hline Repeat the class & & \\
\hline The first class & 6 & 5.5 \\
\hline Total: & $\mathbf{1 1 0}$ & $\mathbf{1 0 0}$ \\
\hline
\end{tabular}

According to the data presented in Table 26., children with disabilities had excellent success in $17.3 \%$ of cases, $23.6 \%$ of cases were very good, $44.5 \%$ were good, $8.2 \%$ were satisfying, only one pupil was behaviour of children on the class failing, while there were no pupils who repeated the class.

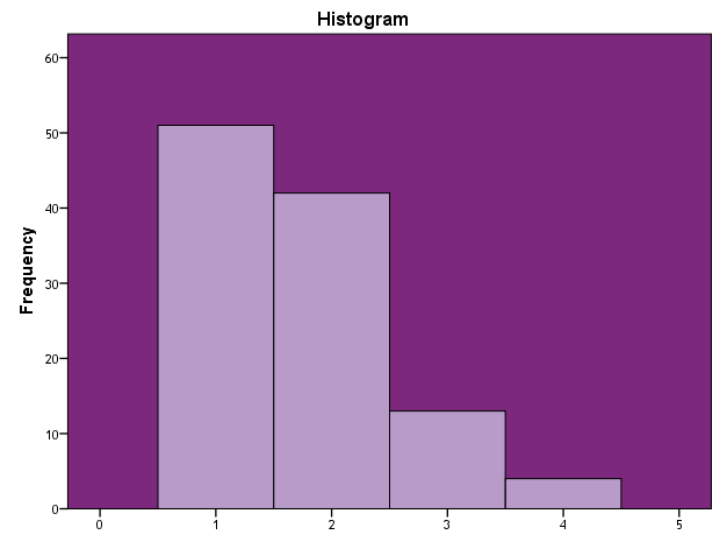

Behavior of children with disabilities on the class on the class

\begin{tabular}{|l|c|c|}
\hline \multirow{2}{*}{$\begin{array}{l}\text { Behaviour of children } \\
\text { on the class }\end{array}$} & \multicolumn{2}{|c|}{ Children } \\
\cline { 2 - 3 } & No. & \% \\
\hline Adequately & 51 & 46.4 \\
\hline Restless, Careless & 42 & 38.2 \\
\hline Recluse, timid & 13 & 11.8 \\
\hline Frightened, sensitive & 4 & 3.6 \\
\hline Total: & $\mathbf{1 1 0}$ & $\mathbf{1 0 0}$ \\
\hline
\end{tabular}

Teachers evaluate the behaviour of children on the class as adequate in $46.4 \%$ of cases. In other cases, it is not evaluated as adequate. 
Table 28. The relation of children with disabilities to teachers

\begin{tabular}{|l|c|c|}
\hline \multirow{2}{*}{$\begin{array}{l}\text { The relation of children } \\
\text { to teachers }\end{array}$} & \multicolumn{2}{|c|}{ Children } \\
\cline { 2 - 3 } & No. & No. \\
\hline Adequately & 65 & 59.1 \\
\hline Excessive relation & 19 & 17.3 \\
\hline Spite, disobedience & 12 & 10.9 \\
\hline Open aggression & 14 & 12.7 \\
\hline Total: & $\mathbf{1 1 0}$ & $\mathbf{1 0 0}$ \\
\hline
\end{tabular}

Table 28. shows data about the relation of children from the Integrated classes to teachers. In most cases, $59.1 \%$, this relation is evaluated as adequate for teachers. It is not negligible data that $40 \%$ of children with disabilities have an inadequate relation towards teachers.

Table 29. The relation of children with disabilities

towards their peers

\begin{tabular}{|l|c|c|}
\hline \multirow{2}{*}{$\begin{array}{l}\text { Description of relation } \\
\text { towards peers }\end{array}$} & \multicolumn{2}{|c|}{ Children } \\
\cline { 2 - 3 } Popular, favourite & No. & $\mathbf{\%}$ \\
\hline Accepted & 9 & 8.2 \\
\hline Isolated, unaccepted & 88 & 80.0 \\
\hline Total: & 13 & 11.8 \\
\hline
\end{tabular}

With the largest number of tested children, the relation towards peers was rated as adequate $80.0 \%$, popular and favourite $8.2 \%$, while $11.8 \%$ isolated and unnoticed.

Table 31. Cooperation of parents with school

\begin{tabular}{|l|c|c|}
\hline \multirow{2}{*}{ Evaluation of cooperation } & \multicolumn{2}{|c|}{ Examinees } \\
\cline { 2 - 3 } & No. & $\mathbf{\%}$ \\
\hline Good cooperation & 83 & 75.5 \\
\hline Occasional contacts & 22 & 20.0 \\
\hline Disinterest & 5 & 4.5 \\
\hline Total: & $\mathbf{1 1 0}$ & $\mathbf{1 0 0}$ \\
\hline
\end{tabular}

Cooperation with parents is on an enviable level, and the assumption is that the development of the IDEP, which is legally supported, has caused such a high level of cooperation.

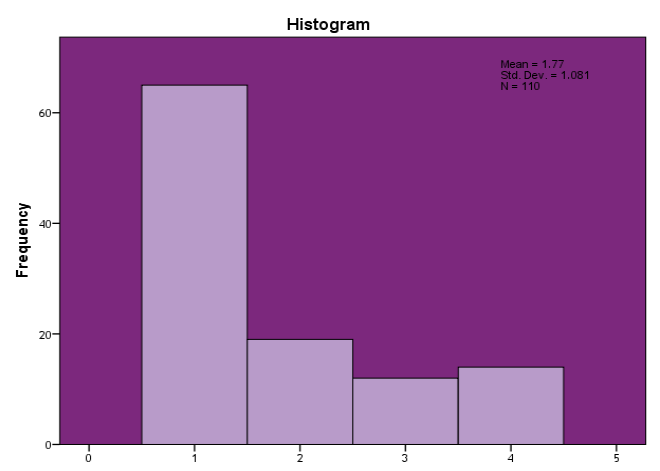

The relationship of children with

Table 30. The absence of children with disabilities from the school

\begin{tabular}{|l|c|c|}
\hline \multirow{2}{*}{$\begin{array}{l}\text { The absence of children } \\
\text { from the school }\end{array}$} & \multicolumn{2}{|c|}{ Children } \\
\cline { 2 - 3 } & No. & $\mathbf{\%}$ \\
\hline No absences & 36 & 32.7 \\
\hline Many justified absences & 71 & 64.4 \\
\hline Many unjustified absences & 1 & 0.9 \\
\hline Often late in school & 2 & 1.8 \\
\hline Total: & $\mathbf{1 1 0}$ & $\mathbf{1 0 0}$ \\
\hline
\end{tabular}

Table 30. shows data about the absence from the school. Children in the Integrated classes children with disabilities, so that their large number of justified $64.4 \%$ of absences has just connected with their state.

Table 32. Socializing children with disabilities with delinquent peers

\begin{tabular}{|l|c|c|}
\hline \multirow{2}{*}{$\begin{array}{l}\text { The existence of delinquent } \\
\text { bonds }\end{array}$} & \multicolumn{2}{|c|}{ Children } \\
\cline { 2 - 3 } & No. & $\%$ \\
\hline No exist & 108 & 98.2 \\
\hline Occasionally connected & 2 & 1.8 \\
\hline Member of the delinquent group & & \\
\hline Total: & $\mathbf{1 1 0}$ & $\mathbf{1 0 0}$ \\
\hline
\end{tabular}

With many children with disabilities, teachers, dialectologists, psychologists, social workers, have not detected the existence of a link between children from the Integrated classes with the peers of delinquent behaviour. 
Table 33. Aggressive behaviour of children with disabilities

\begin{tabular}{|l|c|c}
\hline \multirow{2}{*}{$\begin{array}{l}\text { Forms of aggressive } \\
\text { behaviour }\end{array}$} & \multicolumn{2}{|c}{ Children } \\
\cline { 2 - 3 } & No. & $\mathbf{\%}$ \\
\hline No exist & 68 & 61.8 \\
\hline Physically attacks on others & 23 & 20.9 \\
\hline Verbal attacks on others & 9 & 8.2 \\
\hline They destroy school property & 6 & 5.5 \\
\hline All mentioned forms & 4 & 3.6 \\
\hline Total: & $\mathbf{1 1 0}$ & $\mathbf{1 0 0}$ \\
\hline
\end{tabular}

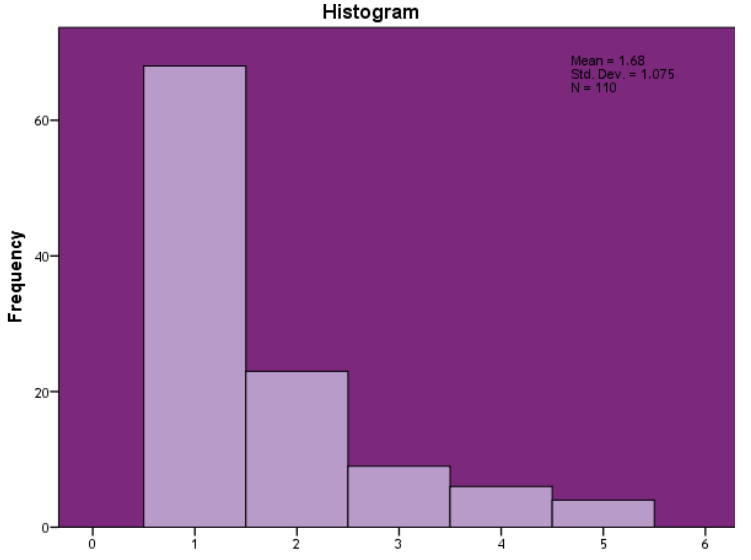

Forms of aggressive behavior

The research found that in 39\% of children with disabilities there is some form of aggressive behaviour.

Table 34. Aggressive behaviour of children with disabilities

\begin{tabular}{|l|c|c|}
\hline \multirow{2}{*}{$\begin{array}{l}\text { Forms of auto aggressive } \\
\text { behaviour }\end{array}$} & \multicolumn{2}{|c|}{ Children } \\
\cline { 2 - 3 } & No. & \% \\
\hline No exist & 83 & 75.5 \\
\hline Self-harm & 27 & 24.5 \\
\hline Suicide attempt & & \\
\hline Total: & $\mathbf{1 1 0}$ & $\mathbf{1 0 0}$ \\
\hline
\end{tabular}

Table 34. shows that a significant number of children with disabilities with auto-aggression type is $24.5 \%$.

Table 36. Escaping respondents from home

\begin{tabular}{|l|c|c|}
\hline \multirow{2}{*}{$\begin{array}{l}\text { Escaping from the } \\
\text { home }\end{array}$} & \multicolumn{2}{|c|}{ Children } \\
\cline { 2 - 3 } & No. & $\mathbf{\%}$ \\
\hline Not present & 106 & 96.4 \\
\hline Periodically & 3 & 2.7 \\
\hline Frequently & 1 & 0.9 \\
\hline Total: & $\mathbf{1 1 0}$ & $\mathbf{1 0 0}$ \\
\hline
\end{tabular}

Occasionally and frequently escape of children with disabilities was detected in $3.6 \%$ of children

Table 38. Thefts in the school by children with disabilities

\begin{tabular}{|l|c|c|}
\hline \multirow{2}{*}{ Thefts in the school } & \multicolumn{2}{|c|}{ Children } \\
\cline { 2 - 3 } & No. & \% \\
\hline Not present & 109 & 99.1 \\
\hline Periodically & 1 & 0.9 \\
\hline Frequently & & \\
\hline Total: & $\mathbf{1 1 0}$ & $\mathbf{1 0 0}$ \\
\hline
\end{tabular}

Table 35. Escaping children with disabilities from the school

\begin{tabular}{|l|c|c|}
\hline \multirow{2}{*}{$\begin{array}{l}\text { Escaping from the } \\
\text { school }\end{array}$} & \multicolumn{2}{|c|}{ Children } \\
\cline { 2 - 3 } & No. & \% \\
\hline Not present & 108 & 98.2 \\
\hline Periodically & 2 & 1.8 \\
\hline Frequently & & \\
\hline Total: & $\mathbf{1 1 0}$ & $\mathbf{1 0 0}$ \\
\hline
\end{tabular}

Based on the data presented in Table 35. , we can conclude that a small number of children with disabilities, $1.8 \%$, escapes from classes.

Table 37. Begging and vagrancy of children with disabilities

\begin{tabular}{|l|c|c|}
\hline \multirow{2}{*}{ Begging and vagrancy } & \multicolumn{2}{|c|}{ Children } \\
\cline { 2 - 3 } & No. & \% \\
\hline Not present & $\mathbf{1 0 8}$ & $\mathbf{9 8 . 2}$ \\
\hline Periodically & $\mathbf{1}$ & $\mathbf{0 . 9}$ \\
\hline Frequently & $\mathbf{1}$ & $\mathbf{0 . 9}$ \\
\hline Total: & $\mathbf{1 1 0}$ & \\
\hline
\end{tabular}

Occasionally and frequently begging and vagrancy were detected in $1.8 \%$ of children of the Integrated classes.

Table 39. Commission of delicts and criminal offenses by children with disabilities

\begin{tabular}{|l|c|c|}
\hline \multirow{2}{*}{$\begin{array}{l}\text { Commission of delicts } \\
\text { and criminal }\end{array}$} & \multicolumn{2}{|c}{ Children } \\
\cline { 2 - 3 } & No. & $\mathbf{\%}$ \\
\hline No exist & 109 & 99.1 \\
\hline It exists & 1 & 0.9 \\
\hline Total: & $\mathbf{1 1 0}$ & $\mathbf{1 0 0}$ \\
\hline
\end{tabular}

Theft and the commission of delicts, as well as the criminal offenses of children with disabilities, is 
only represented in two children.

Table 40. Abuse of psychoactive substances in children

\begin{tabular}{|l|c|c|c|l|c|c|}
\hline \multirow{2}{*}{$\begin{array}{l}\text { Abuse of psychoactive } \\
\text { substances in children }\end{array}$} & \multicolumn{2}{|c|}{ Smoking } & \multicolumn{2}{c|}{ Alcohol } & \multicolumn{2}{c|}{ Drugs } \\
\cline { 2 - 7 } & Children & $\mathbf{\%}$ & Children & & Children & $\%$ \\
\hline Not present & 107 & 97.3 & 110 & Not present & 107 & 97.3 \\
\hline Present & 1 & 0.9 & & Present & 1 & 0.9 \\
\hline There are clues & 2 & 1.8 & & There are lies & 2 & 1.8 \\
\hline Total: & $\mathbf{1 1 0}$ & $\mathbf{1 0 0}$ & $\mathbf{1 1 0}$ & Total: & $\mathbf{1 1 0}$ & $\mathbf{1 0 0}$ \\
\hline
\end{tabular}

It was detected that only one student uses cigarettes, while there are indications for two more children. With regard to alcohol and drugs, teachers, professional associates and defectologists said that it was not present in children with disabilities.

\section{CONCLUSION}

Bearing in mind the growing tendency to include children with disabilities in the regular school, then the possible negative consequences of peer rejection, it is necessary to act proactively, and in the school practice include strategies that can contribute to the improvement of peer relationships among children, good peer relationships positively influence on the development of social skills, and that behaviour becomes more social and more flexible [10].

The obtained results are largely confirmed by the current foreign and domestic research, and point to the need for wider social engagement, aimed at building a social model with emphasis on support to families of children with intellectual disabilities from the earliest age, which would enhance emotional and social development, through intervention in stimulating environment. Parents are very important partner in assessing and creating and implementing an intervention. Undesirable behaviour reduces the possibility of learning a child with intellectual disabilities and their participation in everyday family life, and it is necessary to educate parents with strategies to remove unwanted behaviours, and more importantly, to implement programs to foster the development of communication and social skills.

This scientific consideration of the problem indicates that it is necessary to encourage all competent institutions, services and individuals to work together in a harmonized manner, in order that all social potentials be professionally, responsibly and rationally used in recording, monitoring, controlling, correcting and preventing unacceptable behaviour of children and young people.

\section{REFERENCES}

[1] Sakotic, N.(2014). Challenges Toward the FutureI CRAE, 5-15

[2] Sobot, V., Ivanovic-Kovacevic, S., Markovic, J., Srdanovic-Maras, J., Misic-Pavkov, J. (2010). Juvenile delinquency, Engrami, 2010, 32, (3), page 58.

[3] Vukovic, S. (2011)Modern approaches and problems in social prevention of crime, Newspaper, Security, (3) page 95-111.

[4] Mesalic, S., Mahmutagic, A., Hadzihasanovic, H. (2004) Education and Socialization of Students with Delayed Cognitive Development, University of Tuzla, Faculty of Special Education

[5] Bilic, V.(2016) School success of children and young people, growing up in poverty and materially unfavorable conditions, Newspaper, New presence, Zagreb 1, 91-106

[6]Hrncic, J.(1999) Delinquent or patient-Study of family failure, Andrejevic Foundation Belgrade,(1) page96

[7] Nelson, B. A., Gunton, K. B., Lasker, J. N., Nelson, L. B. \& Drohan, L. A. (2008)The psychosocial impact of strabismus in teenagers and adults and the impact of surgical correction. Journal of American Association for Pediatric Ophthalmology and Strabismus, 12 (1), 72-76.

[8] Satterfield, D., Keltner, J. L., Morrison, T. L.(1993) Psychosocial aspects of strabismus study. Archives of Ophthalmology, 111 (8), 100-105.

[9]Tonge, B. J., Lipton, G. L., Crawford, G.(1984) Psychological and educational correlates of strabismus in school children. The Australianand New Zealand Journal of Psychiatry, 18 (1), 
[10] Jablan, B., Mirkovic, A., Stanimirovic, D., Vucinic, V. (2017)Sociometric status of students with developmental disabilities, and students with health problems in regular school, Belgrade defectology school,p.13

[11] Ibralic, F., Smajic, M. (2007): People with intellectual disabilities - contextual approach, Tuzla: Denfas Tuzla, 2007, page 117.

[12] Mujkanovic, E., Vantic, M., Mujkanovic, E.(2015) Frequency and characteristics of undesirable forms of behaviour in children with intellectual disabilities, Center for Hearing and Speech Rehabilitation, Sarajevo, BandH, Faculty of Education and Rehabilitation, Tuzla, p. 109

[13] Erikson, E. H. (1977)Youth, crisis and identity, Pobjeda, Podgorica,p. 136.

[14] Selimovic, H., Tomic, R.(2016) 'Parents' attitudes towards children with behavioural disorders

[15] Mitic, M., (1997)Family and stress, Institute of Psychology, IP Zarko Albulj, Belgrade, (1) 50: 79.

[16] Milosavljevic, M.(1998) Violence against children, Faculty of Political Science, Belgrade,p. 265.

\section{Article history:}

Received 30 November 2021

Accepted 22 December 2021 